\title{
State Capture: From Yeltsin to Putin
}

\author{
Evgeny Yakovlev and Ekaterina Zhuravskaya ${ }^{ \pm}$
}

\section{State capture during Yeltsin's governance}

After collapse of the Soviet Union a new force appeared in Russia, which was later to affect the country's economy and politics. The name of the force was oligarchy. A large-scale privatization of state assets in the beginning of the 1990s, which led to a growth in income inequality, was combined with weak legal and political institutions, a legacy from the communist times. The fragility of democratic institutions and the state's poor accountability to the public made the governments in Russia easily susceptible to "capture" by the new wealth. Politically powerful firms influenced the very rules of the game in the economy: they created obstacles to emergence and development of competitive businesses, changed the direction and speed of economic reforms. ${ }^{1}$ The 1999 BEEPS $^{2}$ survey confirmed that state capture was deeply rooted in economic and political processes of the country: in the composite index of state capture among 20 transition countries Russia ranked fourth ${ }^{3}$.

At the same time, decentralization brought Russian regions a greater autonomy and the opportunity to pursue their own economic policies. Regional economic policies and, in particular, their susceptibility to capture varied significantly depending on industrial concentration, level of education, voter awareness etc. The study by Slinko et. al. (2005) creates a measure of state capture in the Russian regions based on Russian legislation in 1992-2000, and evaluates the effects of capture on politically influenced firms. The authors show that politically powerful firms benefit greatly from their political influence. Compared to firms without political influence, powerful firms' sales and employment grew faster; they invested more and received more profits, and besides, their performance picked up with the growth of capture.

Although there is no evidence that capture had a significant impact on the aggregate economic growth, the study shows that the rest of the economy was suffering from state capture by powerful elites:

- Firms without political influence stagnated, they productivity, sales and investments declined with the increase in capture;

- Regional small business deteriorated, their share of employment and retail turnover went down with the growth in capture.

- Regional budgets were negatively affected as tax collection decreased and arrears to the budgets increased with an increase in the level of state capture.

Who is the most effective Russian regional captor? Studies which have looked at this question are scarce mainly due to the lack of enterprise-level data related to politics. According to the studies, a firm's political power is determined by a firm's size, both in terms of cash (and ability to bribe) and

\footnotetext{
${ }^{ \pm}$Authors are from CEFIR; and CEFIR and CEPR, respectively.

${ }^{1}$ The phenomenon of shaping institutes by powerful businesses is called State Capture. See Olson (1965, 1982), Stigler (1971) for pioneer works. For empirical work on state capture in transition countries see Hellman, Jones, Kaufmann, and Schankerman, 2000; Hellman and Schankerman, 2000; Hellman, Jones, and Kaufmann, 2003; Hellman and Kaufmann, 2003; Hellman, 1998; Slinko et al, 2003; Yakovlev and Zhuravskaya, 2003.

2 BEEPS are Business Environment and Enterprise Performance Surveys, conducted jointly by the World Bank and the European Bank for Reconstruction and Development in transition countries in 1999 and 2002. See http://info.worldbank.org/governance/beeps/ for survey description, data and research.

${ }^{3}$ See Hellman, Jones, Kaufmann, and Schankerman, 2000; Hellman and Schankerman, 2000; Hellman, Jones, and Kaufmann, 2003; Hellman and Kaufmann, 2003
} 
employment (social significance) ${ }^{4}$, as well as ownership structure. Frye (2002) shows that Russian state-owned firms are engaged in state capture at least as much as private firms. Since the state does not have a tight control over state-owned firms, these firms' managers appropriate both control and cash flows for their private benefit. Yakovlev and Zhuravskaya (2004) show that enterprises, which belong to foreign or regional private owners, are more likely to be captors whereas enterprises owned by federal private oligarchs are less likely to be captors. They also show that enterprises, which are members of larger financial-industrial groups or members of groups that had engaged in loans-forshare schemes, are more effective captors. As for industrial structure, the World Bank study (2000) shows that enterprises, which operate in natural resource sectors, extract more rents and so are more likely to be captors.

\section{State Capture under Putin}

All empirical studies of state capture so far examined the phenomenon during the first eight years of Russian capitalism, i.e. during President Yeltsin's regime. It is widely accepted, however, that there has been a big shift in the relationship between the state and businesses during President Putin's first and second terms. A number of the richest and most famous Russian businessmen found themselves behind bars or in exile abroad. Also, the centralization process, which can eventually reduce local capture, has been initiated. Do these factors lead to a decrease of capture and redistribution of power to new winners?

Our analysis uses supplement of data on preferential treatments of large firms by regional legislation, which is described in Slinko et al. (2005). The dataset contains firms that were listed among the five largest firms in terms of sales at least once during $1992-2000$ in each of 72 Russian regions (autonomous republics and administrative entities in the Caucasus excluded). For each of these firms the number of regional laws that gave preferential treatment to the firm was counted. Preferential treatments include tax breaks, investment credits, subsidies, subsidized loans, loans with a regional budget guarantee, official delays in tax payments, subsidized licensing, free grants of state property, and a special “open economic zone” status.

For this publication the dataset was extended by adding observations up to 2003 and a sub-sample of firms that were among the five largest in terms of sales in 72 regions for the period from 2001 to 2003. In total, the dataset contains preferential treatments for 1065 firms for the years from 1992 to $2003^{5}$.

We are mainly interested in concentration of political power in the hands of a few, and we follow the methodology described in Slinko et al. (2005). State capture is measured as a concentration of preferential treatments in the region; and a firm's political influence is measured as a share of preferential treatments given to the firm in the total number of preferential treatments in the region. Table1 presents level of state capture (average through years concentration of preferential treatments) in Russian regions during President Yeltsin's $2^{\text {nd }}$ term and $1^{\text {st }}$ Putin governance.

\footnotetext{
${ }^{4}$ For theoretical prediction see Shleifer, Vishni, 1994, for evidence from Russian regions see Slinko et al, 2003, Yakovlev and Zhuravskaya, 2003

${ }^{5}$ For the analysis of firm ownership structure we use data from the intersection of two data sets: one described in the text body above and the other one on controlling owners of firms from the World Bank's study "Who owns Russia” (see Yakovlev and Zhuravskaya, 2004)
} 
Figure 1a. Average Concentration of Preferential Treatments in President Yeltsin's terms and President Putin's $1^{\text {st }}$ term, 1994-2003

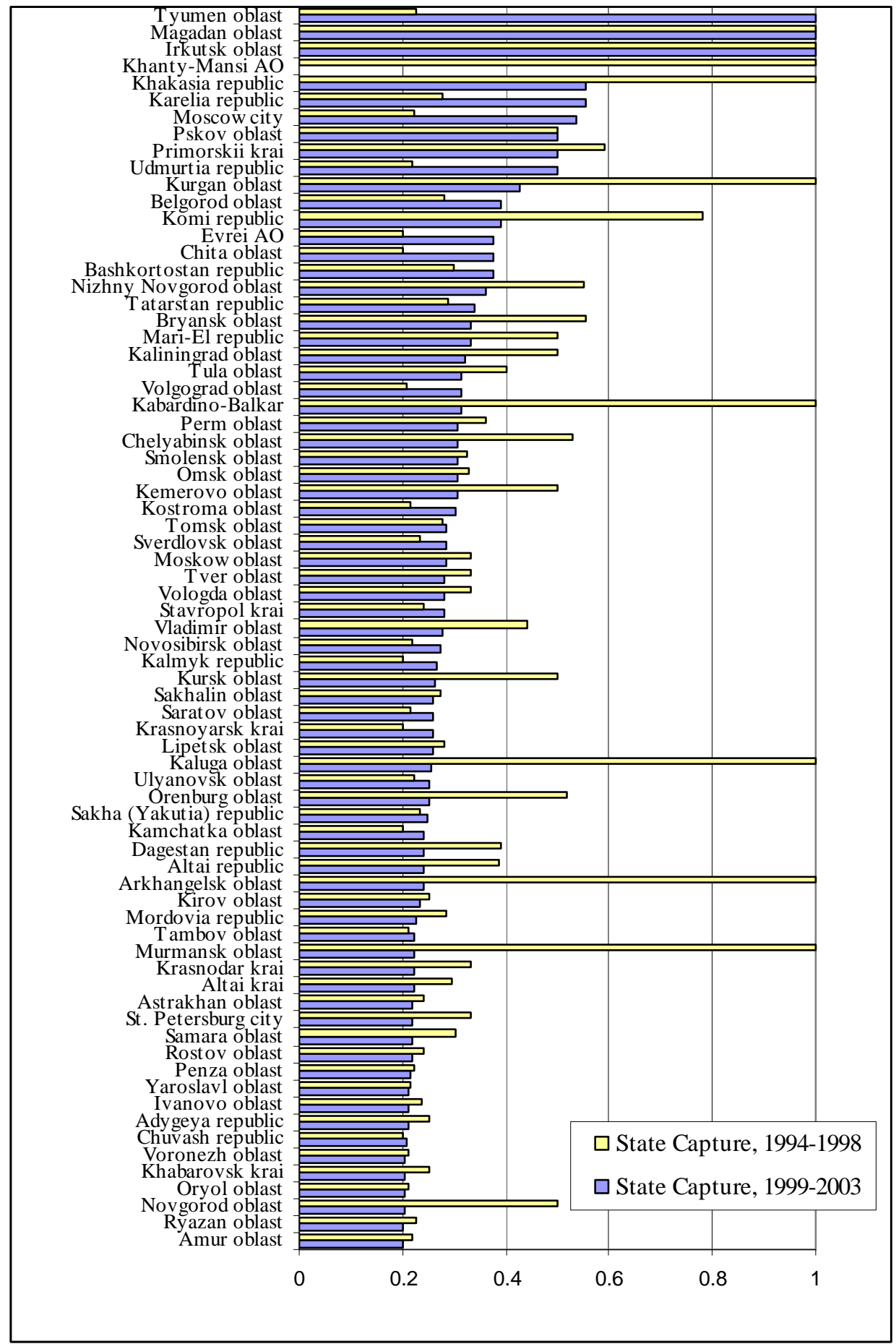

Figure 1b. Map - Average Concentration of Preferential Treatments in President Yeltsin's terms and President Putin's $1^{\text {st }}$ term, 1994-2003

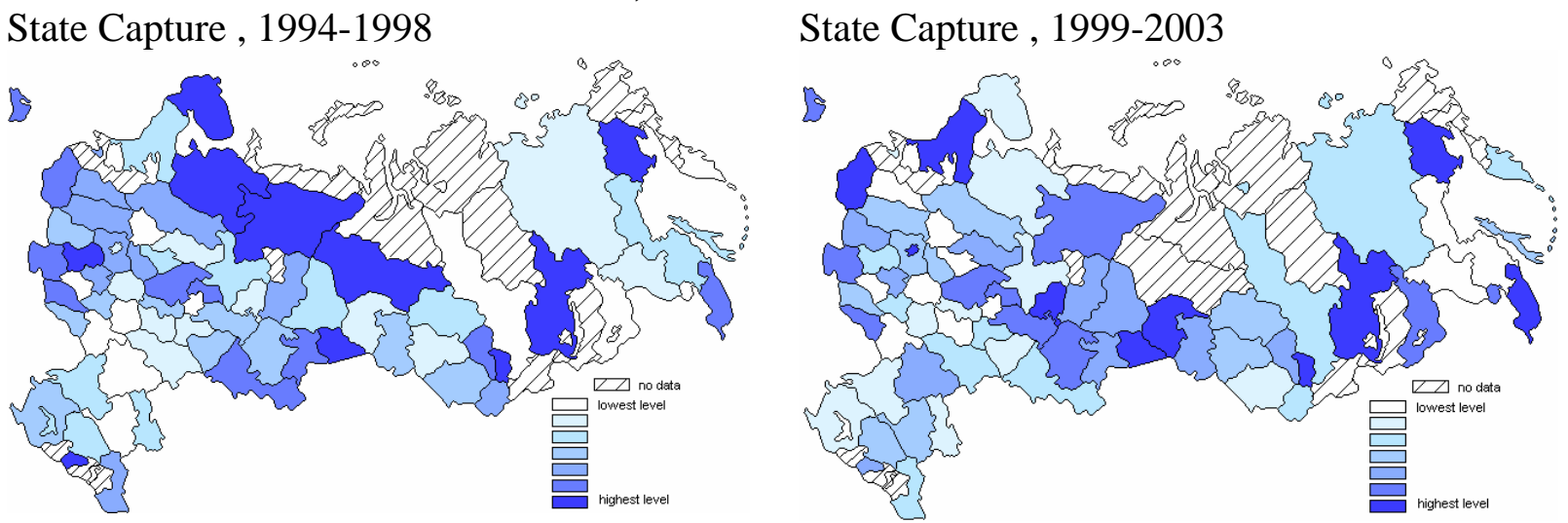




\section{Has capture decreased?}

In contrast to Yeltsin whose political term was notorious for creating and strengthening oligarchs, Putin began his first term in the office by fighting the most famous of them: Berezovsky, Khodorkovsky, Gusinsky, and Lebedev. Fighting oligarchs was again high on the agenda during his second election campaign. In addition, Putin attempted centralization process, restricting autonomy of regional political elites and moved political and economic power from the regions to the federal center ${ }^{6}$. A new tax law, which restricted the use of individual tax breaks, was adopted, as well as a number of laws, aimed at easing the burden of business regulation. ${ }^{7}$ A new anti-corruption campaign was launched and some governors who were considered most corrupt, e.g. Rutskoy in Kursk region and Nazdratenko in Primorsky region, were not permitted to run for re-election. The governor of Yaroslavl region, Lisitsin, was under a criminal investigation in early fall of 2004 because of pursuing illegal paternalistic policies towards regional business.

Considering the initiatives described above, one can expect a significant decrease in the level of capture in the regions and in its negative effect on the regional economy. However, various polls and President Putin himself in his annual address to the Federal assembly in 2003 drew attention to the blooming corruption in various government bodies. ${ }^{8}$ Similarly, our data shows no significant change in the level of capture in the regions: the level of state capture grew gradually during Yeltsin's first term and remained almost unchanged during Yeltsin's $2^{\text {nd }}$ term and Putin's $1^{\text {st }}$ term (see Figure 2). State Capture measure in the first four years of Putin's presidency strongly significantly correlates with the measure in Yeltsin's $2^{\text {nd }}$ term and with alternative corruptions measures (see Table 1). ${ }^{9}$

\section{Figure 2. Regional State Capture (Average PTC) and average number of preferential treatments during Yeltsin's and Putin 's governance.}

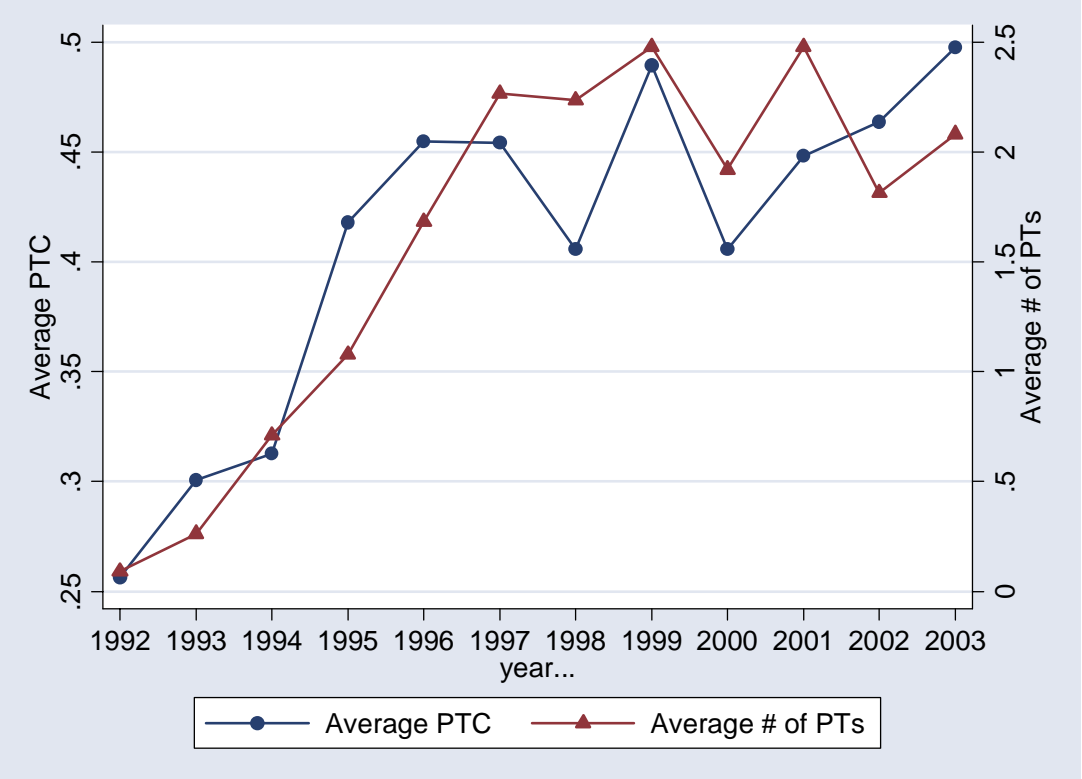

Table 1. Correlation between State capture (2000-2003) and other corruption indexes.

\begin{tabular}{|c|c|c|c|c|c|c|}
\hline & $\begin{array}{l}\text { \# of PTs, } \\
\text { 2000-2003 }\end{array}$ & $\begin{array}{c}\text { PTC, } \\
\text { 1996-1999 }\end{array}$ & $\begin{array}{l}\text { \# of PTs, } \\
\text { 1996-1999 }\end{array}$ & $\begin{array}{c}\text { State Capture } \\
\text { (INDEM\&TI), } \\
2000\end{array}$ & $\begin{array}{c}\text { Business } \\
\text { Capture } \\
\text { (INDEM\&TI), } \\
2000\end{array}$ & $\begin{array}{c}\text { Administrative } \\
\text { corruption } \\
\text { (INDEM\&TI), } \\
2000\end{array}$ \\
\hline PTC, 2000-2003 & $-0.37^{\star \star}$ & $0.25^{\star \star}$ & -0.09 & 0.14 & $0.30^{*}$ & $0.43^{\star \star}$ \\
\hline \# of PTs, $2000-2003$ & & $-0.3^{\star *}$ & $0.48^{* *}$ & -0.10 & -0.13 & -0.24 \\
\hline
\end{tabular}

\footnotetext{
${ }^{6}$ Seven large federal districts were created and took away some regional autonomy.

7 See CEFIR study "Monitoring the Administrative Barriers to Small Business Development in Russia", 2003

${ }^{8}$ According to ROMIR polling agency (ww.romir.ru), people put unsuccessful anti-corruption measures as the second biggest failure of President Putin.

${ }^{9}$ State Capture measure in Yeltsin's governance also correlate with alternative corruption indexes (see Slinko et al, 2003).
} 
State Capture still negatively affect on the small business development and growth of firms without political power. Output of small businesses and retail turnover go down with increase in State Capture (see Figure 3). Growth in profitability, productivity, sles, employment and investment of firms without political connections slow down in high captured environments (see Figure 4).

Figure 3. State Capture and small business growth.
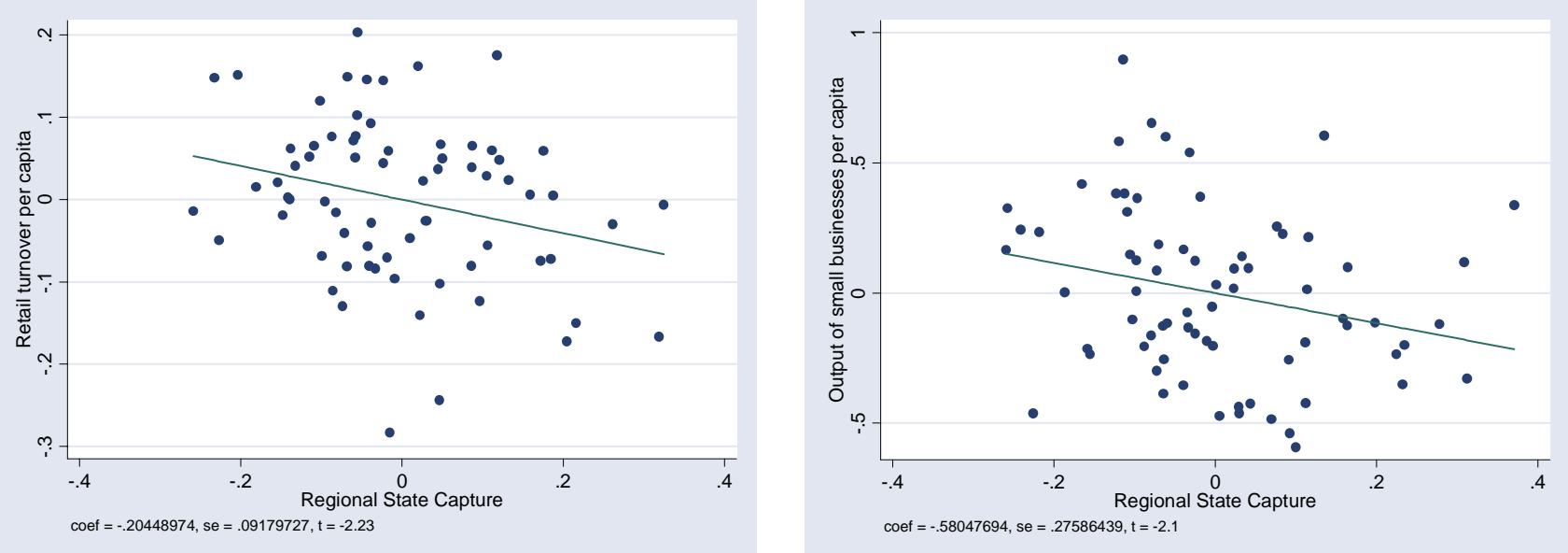

Figure 4. State Capture and performance of firms without political power.

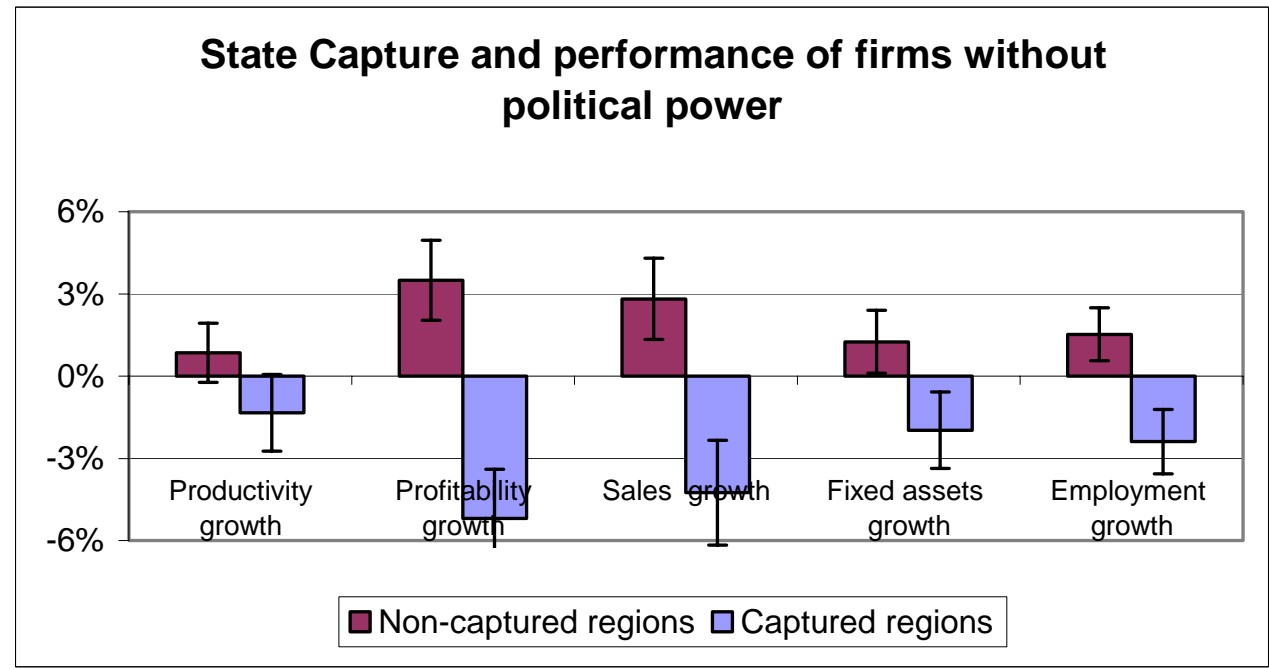

Using the available data we present an example of the effect of a partial reform aimed at fighting corruption. At the end of 1999, a tax law restricting individual tax breaks was enacted. Tax breaks were the most popular type of preferential treatments constituting one-third of the total number of preferential treatments. Nevertheless, the law has not resulted in any considerable change of either the number or concentration of preferential treatments provided by the regions to firms. The law has only led to a change $\mathrm{f}$ the type of preferential treatments given out: as figure 5 shows, the share of tax breaks has significantly decreased, whereas the share of subsidies, subsidized budget loans, budget guaranties of credits and subsidized energy prices has significantly increased. 
Figure 5. Distribution of preferential treatment s by types

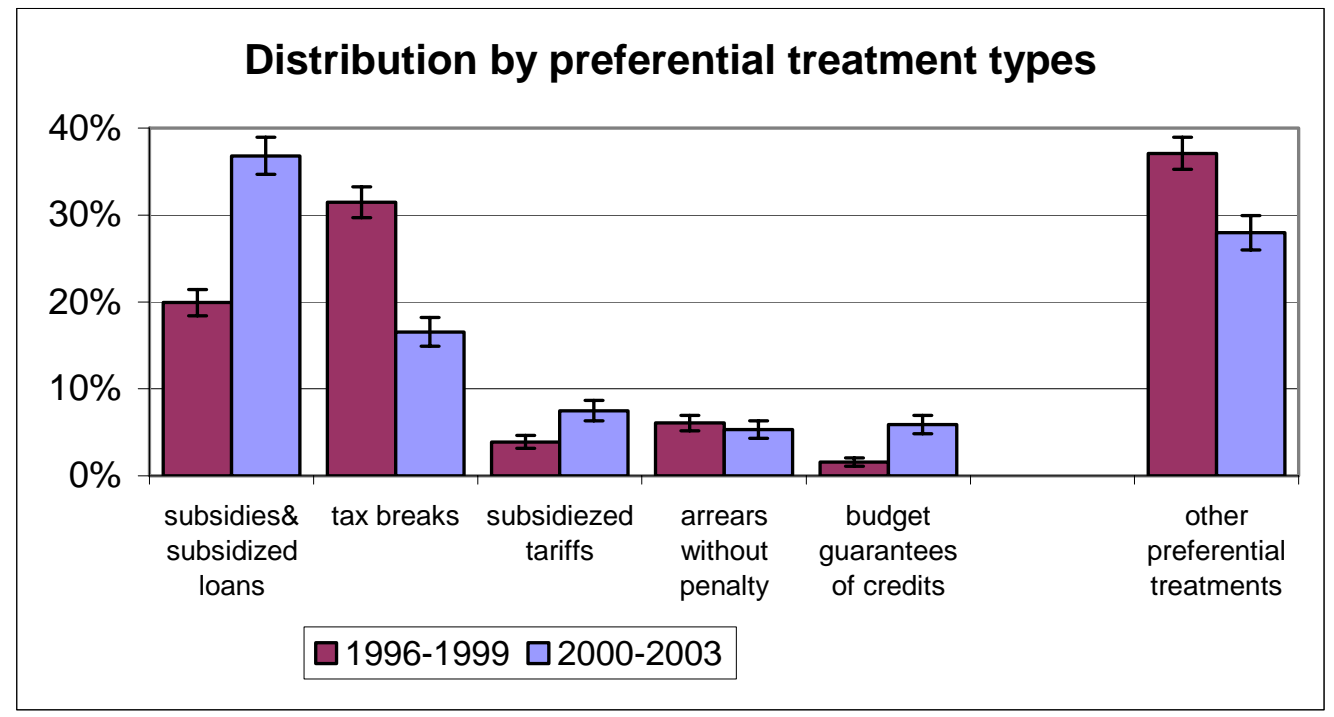

\section{Who has received preferential treatments?}

The question here is whether Putin's measures, in particular his attacks on oligarchs and consolidation of power in the hands of the federal center, have led to real redistribution of political power, rise of new financial-industrial groups and fall of the previous favorites. We address this question by looking at firms’ characteristics, such as firms’ size and industrial structure.

Theory predicts concentration of political power in hands of biggest and richest enterprises. The means of their bargaining with politicians are both big employment, which has a great political benefit to politicians and rents that enterprises can use to bribe politicians. During Yeltsin, firms with bigger employment, bigger output and capital, firm in extract industries, and firms that belong to bigger financial-industrial group are likely to experience the political influence. Things have not changes under Putin. Figure 6 shows that firms with bigger output and employment relative to other firms in the regions received more preferential treatments. Figure7 shows, that firms that belong to bigger financial-industrial group are also likely to be a successful captors. Finally, figure 8 shows that average political influence of firms in extract industries is greater than influence of firms from all other industries, except machine-building and electricity industries.

Figure 6. Firm's size and political power

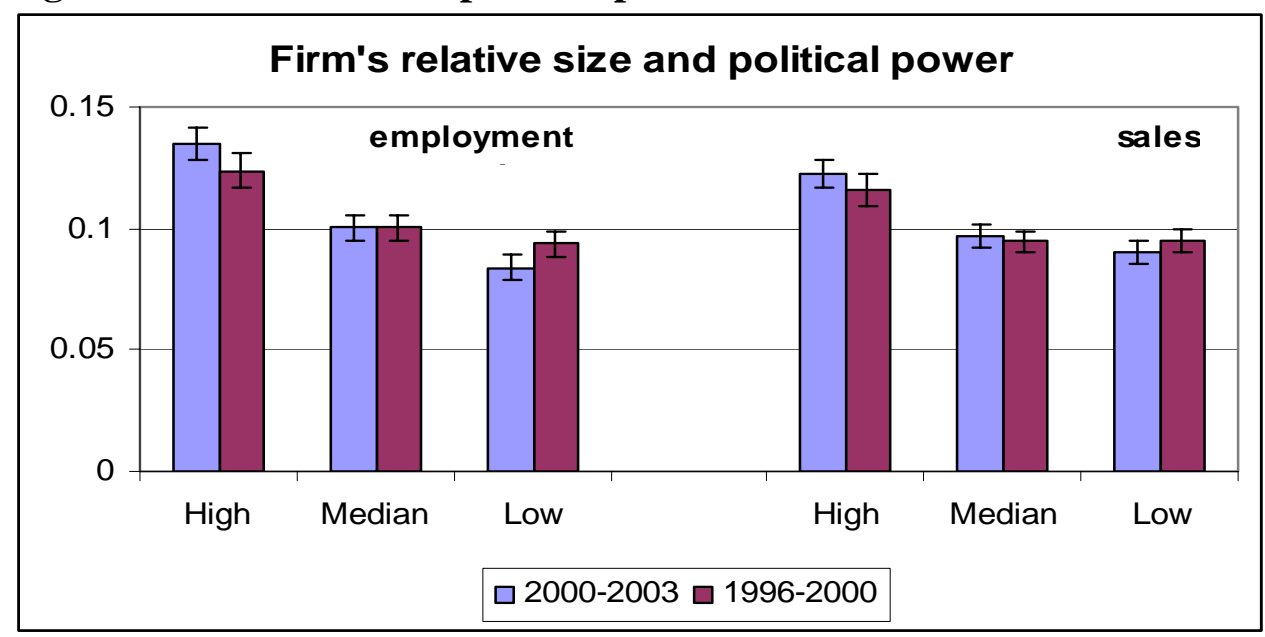


Figure 7. Financial-industrial group's size and firm's political power

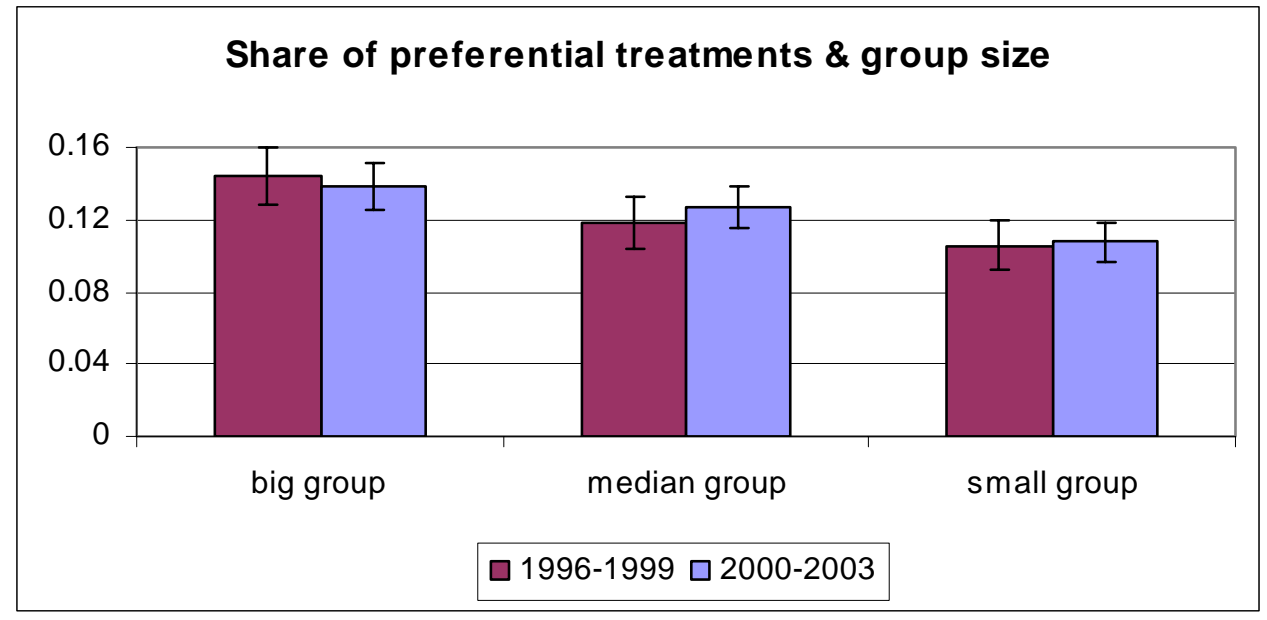

Figure 8. Industry structure and firm's political power

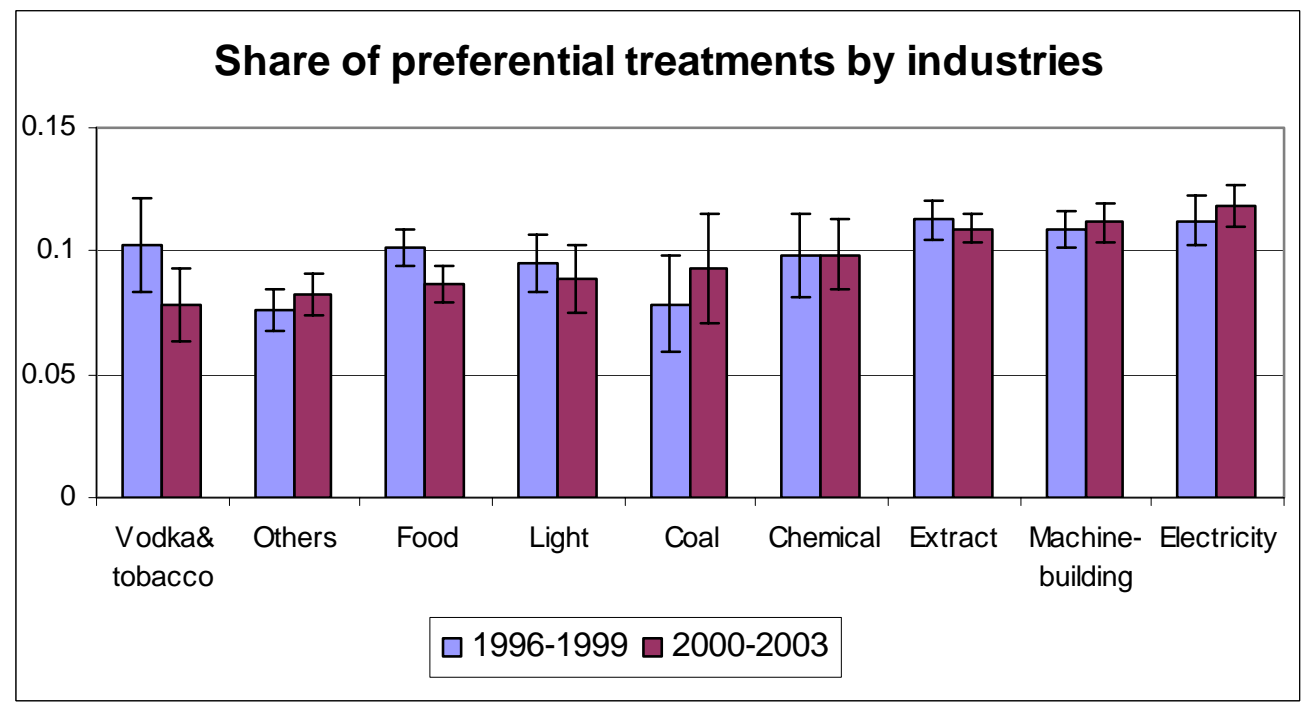

Concentration of political power in the center during Putin's administration can be traced in the data: enterprises that belong to federal government, became the most effective lobbyists during Putin's governance, whereas enterprises engaged in loans-for-shares schemes and enterprises that belong to regional government lost their political power. In Putin's governance only one group, enterprises in federal ownership, received significantly more preferential treatments. (see Figure 9).

Figure 9. Ownership structure and firm's political power

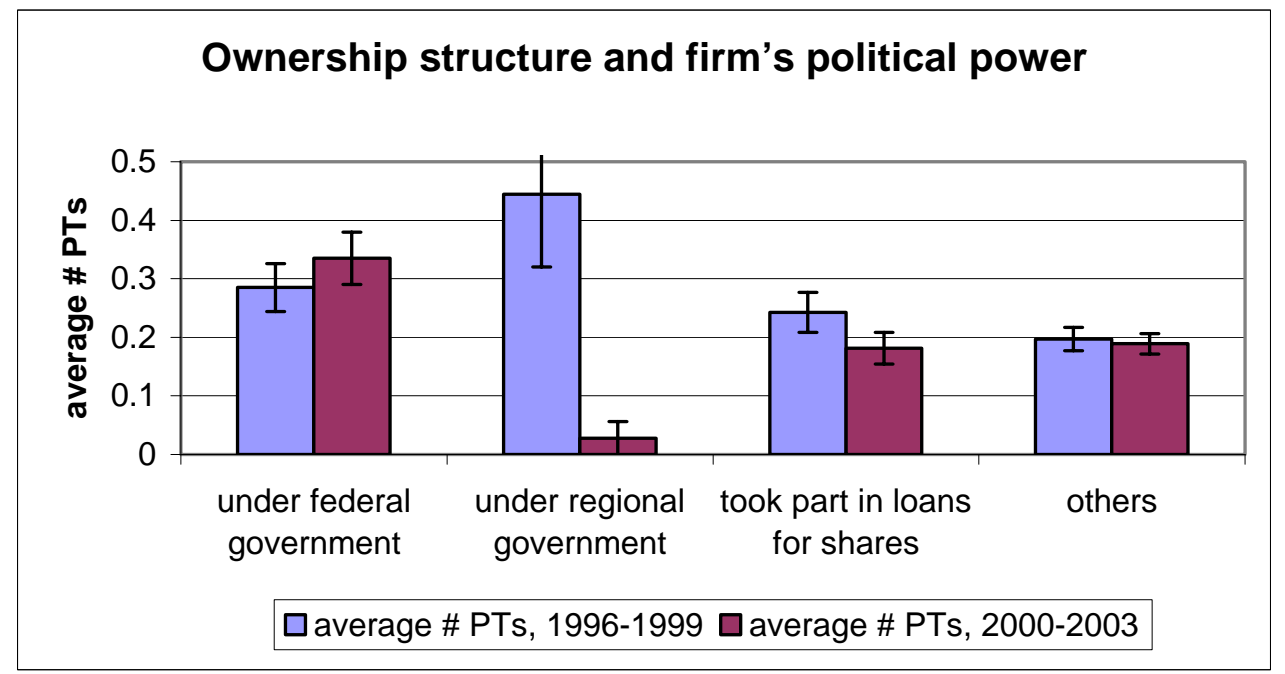


To summarize, our study shows that there have been no significant changes in the overall level of capture. The only changes we observed were in the structure of most powerful industrial groups: firms that belong to the federal government have become the most politically powerful. 